DEPÓSITO LEGAL ZU2020000153

Esta publicación científica en formato digital

es continuidad de la revista impresa

ISSN 0041-8811

E-ISSN 2665-0428

Revista

de la

Universidad

del Tunlia

Fundada en 1947

por el Dr. Jesús Emrique Lossada

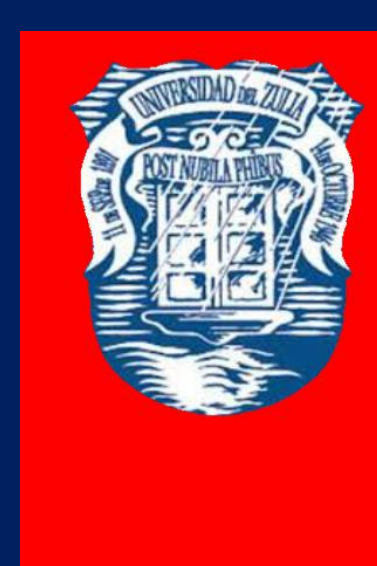

Ciencias

Sociales

y Arte

Aกัต 11 No 31

Septiembre - Diciembre 2021

Tercera ípoca

Maracailbo-Venezuela 


\title{
Inactivity of public authority as a subject of land dispute in administrative legal proceedings
}

\author{
Iryna Pyvovar * \\ Oksana Kuzmenko ** \\ Pavlo Liutikov *** \\ Margaryta Liutikova **** \\ Serhiy Kuvakin $* * * *$
}

\begin{abstract}
In recent years, conflicts in land relations between citizens and government have been increasingly occurring in Ukraine. On the one hand, citizens are striving to realize their right to receive a land plot free of charge, on the other hand, authorities are trying to ignore the corresponding statements of citizens. The purpose of this research is to formulate a legal position concerning the inactivity of authorities in relations arising from the initiative of citizens regarding granting them permission for the development of a land management plan with the subsequent transfer of a land plot into ownership, as well as to determine the optimal way to protect the violated rights of citizens as a result of unlawful inactivity of public authorities. The study has been characterization and identification of peculiarities of application of the principle of tacit consent in land permission relations; indicated ways of protecting the rights of an individual as a result of unlawful inactivity of a powerful subject; established nature of the discretionary powers of the competent authorities. The importance and value of research are complex in nature and is revealed in its social significance since it consists in publication and raising problematic issues in the land sphere for public discussion; the economic value is manifested in helping to resolve real estate ownership problems; legal significance consists in determining perspective directions of legal and regulatory improvement of land relations; the applied value which is manifested in the promotion of the activities of local self-government bodies and administrative justice.
\end{abstract}

KEYWORDS: administrative justice, administrative legal proceedings, public land dispute, inactivity of public authority.

* PhD in Law, Associate Professor, Department of Constitutional and Administrative Law, National Aviation University, Kyiv, Ukraine, https://orcid.org/0000-0002-0084-1112, e-mail: panipyvovar@gmail.com

** Doctor of Law, Professor of the Department of Theory and History of Law, Kyiv National Economic University named after Vadym Hetman, Kyiv, Ukraine, https://orcid.org/0000-00020830-766X

*** Doctor of Law, Associate Professor. Head of the Department of Administrative and Customs Law of University of Customs and Finance, Zaporizhzhya, Ukraine, https://orcid.org/0000-0001-61730128

**** PhD in Law, Doctoral student at the Department of Administrative and Business Law of Zaporizhzhya National University, Zaporizhzhya, Ukraine, https://orcid.org/0000-0002-6576-2458 $* * * *$ PhD in Law, Associate Professor, Department of Administrative and Customs Law, University of Customs and Finance, Ukraine, https://orcid.org/0000-0003-1032-6736

Recibido: 01/06/2020

Aceptado: 30/07/2020 


\section{Inactividad de la autoridad pública como tema de disputa territorial en procedimientos legales administrativos}

RESUMEN

En los últimos años, los conflictos en las relaciones territoriales entre los ciudadanos y el gobierno se han producido cada vez más en Ucrania. Por un lado, los ciudadanos se esfuerzan por hacer efectivo su derecho a recibir una parcela de tierra de forma gratuita; por otro lado, las autoridades están tratando de ignorar las correspondientes declaraciones de los ciudadanos. El propósito de esta investigación es formular una posición jurídica sobre la inactividad de las autoridades en las relaciones derivadas de la iniciativa de los ciudadanos de otorgarles el permiso para el desarrollo de un plan de ordenamiento territorial con la posterior transferencia de una parcela a la propiedad, así como determinar la forma óptima de proteger los derechos vulnerados de los ciudadanos como consecuencia de la inactividad ilícita de los poderes públicos. El estudio ha consistido en la caracterización e identificación de peculiaridades de la aplicación del principio de consentimiento tácito en las relaciones de permisos de tierras; indica formas de proteger los derechos de un individuo como resultado de la inactividad ilegal de un sujeto poderoso; establece el carácter de las facultades discrecionales de las autoridades competentes. La importancia y el valor de la investigación son de naturaleza compleja y se manifiesta en su trascendencia social, ya que consiste en publicar y plantear cuestiones problemáticas en el ámbito territorial para la discusión pública; el valor económico se manifiesta al ayudar a resolver los problemas de propiedad inmobiliaria; el significado legal consiste en determinar direcciones de perspectiva de mejora legal y regulatoria de las relaciones territoriales; el valor aplicado, que se manifiesta en la promoción de las actividades de los órganos de autogobierno local y la justicia administrativa.

PALABRAS CLAVE: justicia administrativa, proceso judicial administrativo, disputa de tierras públicas, inactividad del poder público.

\section{Introduction}

The current development of economic relations in Ukraine in general, and property relations in the field of land management in particular is in a difficult state. Against the backdrop of the global economic crisis, one of the most resonant reforms, namely land reform is gradually implemented in Ukraine. Although such a reform is more relevant to the agricultural land market (Draft Law on Amendments to Certain Legislative Acts of Ukraine Concerning the Circulation of Agricultural Lands, No. 2178 on 25/9/2019), it has only further intensified the interests of citizens in the issue of free allocation of land plots of different types of designated purpose into ownership. A lot of citizens, who have not yet exercised their constitutional right to free allocation of land into ownership, feared that once one 
REVISTA DE LA UNIVERSIDAD DEL ZULIA. 3época. Año 11 N 31, 2020

opened the land market, they will not be able to exercise it and all unallocated land plots will be only for sale. Although such situation is premature and unreasonable, it generates a sharp widespread concern about the land. Obviously, in the context of the almost complete absence of free land plots in cities, the most of those who wishes started to look for a land plot in rural areas. It is well known that due to the absence of legal restrictions on the obligatory connection between the place of residence of such citizen and the location of the desired land plot, as well as the number of submitted applications, citizens make numerous applications to different territorial communities. Under such conditions, take place, firstly, fierce competition between the land claimants; and secondly, confrontation between the citizens who made an application and the local authorities vested to consider such applications.

And if in the first case the "struggle" for exercising this right is relatively equal, then in the second case the forces of confrontation are recognized as unequal because of the extremely wide range of possibilities of manipulation and abuse by the authorities. This state is also proved by the results of a sociological survey, in which more than $90 \%$ (486 persons) of the respondents said that they faced with artificial bureaucratic obstacles in communication with the representatives of local self-government bodies in the process of solving land issues of the mentioned type. At the same time, it should be noted that almost $70 \%$ (340 persons) of this category of citizens answered that they had experience of officials' refusal to accept appropriate applications under any pretexts. In addition, the results of the questionnaire made it possible to ascertain once more that there is one of the most common ways of confrontation between the authorities and the applicants for free allocation of land plots. Thus, more than $65 \%$ of the surveyed citizens mentioned that they did not receive any response to their first "land" application to the local self-government body and were forced either to make the second application or file a complaint or go to court to defend their rights. This state of the work of the authorities clearly does not meet the principles of the purpose of the authorities and their interaction with the population, and attempts to find justice in the court have versatile and often quite opposite nature, which generally actualizes the scientific research of this issue.

\section{Purpose and Objectives of Study}

The purpose of this research is to formulate a legal position concerning the inactivity of authorities in relations arising from the initiative of citizens regarding granting them 
REVISTA DE LA UNIVERSIDAD DEL ZULIA. 3época. Año 11 N 31, 2020

permission for the development of a land management plan with the subsequent transfer of a land plot into ownership, as well as to determine the optimal way to protect the violated rights of citizens as a result of unlawful inactivity of public authorities.

To achieve this goal, the following objectives were solved: carrying out a legal assessment of inactivity of a power entity on the citizens' request for granting permission for the development of a land management plan; characterization and identification of peculiarities of application of the principle of tacit consent in land permission relations; finding out ways of protecting the rights of an individual as a result of unlawful inactivity of a powerful subject; establishing the nature of the discretionary powers of the competent authorities.

\section{Object and Subject of Study}

The above-mentioned allows one to identify the object of the research. These are land relations that arise between the authorities and citizens regarding the allocation of land plots on a free basis, as well as the relations of administrative justice in this field. The subject of the research is the management activities of the competent authorities as well as the enforcement activities of the judicial authorities.

\section{Research Methods}

The research is based on sociological and special legal methods. The method of Quantitative sampling was used to collect information on court cases of administrative jurisdiction, in which the inactivity of local self-government bodies in land relations was discussed, as well as to select categories of citizens for a sociological survey. Selection of citizens was made according to the territorial principle and covered eight regions (Kyiv, Zhytomyr, Chernihiv, Sumy, Vinnytsia, Kirovohrad, Cherkasy, Poltava), and according to the age criterion the selection of citizens ranged from 25 to 65 years of age. The sample size of 540 respondents were citizens who have previously applied or who at the moment of survey made an application to local self-government authorities concerning the allocation of land plots. The legal aspects of the research were provided by methods of comparative analysis, by which was carried out a comparison of case-law of Ukrainian courts of different instances and the decisions of the European Court of Human Rights. The managerial method of correlation of classifications allowed to develop the concept of classification of permitting activities of power entities in the field of allocation of a land plot into ownership to 
REVISTA DE LA UNIVERSIDAD DEL ZULIA. 3época. Año 11 N 31, 2020

administrative services, which along with the method of legal logical comparisons contributed to the distinguishing subjective law to citizens to which corresponds the relevant legal obligation of power entity. Methods of empirical legal analysis, expert assessments, as well as systematization and differentiation ensured the separation of court cases, the legal positions of judges in determining the nature of the discretionary powers of local self-government bodies in land legal relations.

\section{Research Results and Discussion}

4.1. Legal Qualification of the Failure to Provide any Written Response by a Power Entity to Grant Permission/to Refuse to Grant Permission for the Development of a Land Management Plan

Considering the general procedure for granting permission for the development of a land management plan for allocation of a land plot, it is necessary to point to part (7) of article (118) of the Land Code of Ukraine No. 2768-III for 2001, which provides that the relevant executive authority or local self-government body, which transfers land of state or communal possession into ownership in accordance with the powers specified in article (122) of this Code, examines the request within a month and gives permission for the development of a land management plan for allocation of a land plot or gives a reasonable refusal to grant it.

Based on this general rule and due to the classificational correlation of the activities of authorized body for granting permission/refusal to develop a land management plan for land plot allocation into ownership with activities concerning providing administrative services, we have conclude that in these relations the citizen has a subjective right, namely the right to apply for an administrative service (permission), and a corresponding power entity has an existing legal obligation, namely to make an appropriate decision on such appeal. In addition, considering that a land management plan for a land plot allocation into ownership is one of the types of documentation on land management (para. e part 2 of article 25 of the Law On Land Management No. 858-IV for 2003), therefore to such activities of power entities are made other legislative demands, in particular part (2) of article (22) of the Law No 858-IV. This rule stipulates that the decision of the executive authorities or local self-government bodies to grant permission for the development of documentation on land management is made only within the time limits and only in cases provided by this Law and the Land Code 
REVISTA DE LA UNIVERSIDAD DEL ZULIA. 3época. Año 11 N 31, 2020 Iryna Pyvovar et al. /// Inactivity of public authority as a subject of land ...360-375

DOI: http://dx.doi.org/10.46925//rdluz.31.22

of Ukraine No. 2768-III. In addition, the law provides a free form of giving (obtaining) such a powerful decision, as well as an unlimited period of its validity.

Therefore, even from the general legal analysis, it can be stated that the current legislation of Ukraine does not provide the right of power entity to refrain from making an appropriate decision after consideration of the issue of granting permission for the development of a land management plan for a land plot allocation.

Thus, the fact that the authorized body does not give a response to the "land" application of a citizen should be considered as unlawful inactivity of a state government body or local self-government body, which consists in ignoring an application/request of citizens. Failure to provide a response should also include providing a response in the form of a letter of rejection after the expiration of month term since the date of submission of the application/request on granting a permission to prepare plan documentation.

\subsection{The Principle of Tacit Consent in Land Permitting Legal Relations}

The legislator foresees the possibility of applying the principle of "tacit consent" in the mentioned types of relations as means of counteracting the inactivity of a power entity. Thus, para. (3) part (7) of article (118) of the Land Code of Ukraine No. 2768-III stipulates that an individual can order a land management plan for the allocation of a land plot without the consent of the authorized body - by the principle of "tacit consent", but under the condition if within a month the authorized body has not provided permission for its development, or a reasonable refusal to grant such permission.

In addition to that, the content of this rule specifies that the application of this principle lies under the right and not the duty of a certain citizen. At the same time, such citizen retains the right to claim from the authorized body a permission for the development of a land management plan for a land plot allocation or a reasonable refusal to grant it, as well as the right to judicial protection in case if it is impossible to exercise this right. This conclusion is also confirmed by the legal position set out in the Supreme Court Resolution No. 806/3095/17 on 10/7/2018.

Notwithstanding, on the one hand, the existence of the said rule of law on the principle of "tacit consent" in these land relations, on the other hand, it should be noted that there is no legislative mechanism for the implementation of this principle, which gives 
REVISTA DE LA UNIVERSIDAD DEL ZULIA. 3época. Año 11 N 31, 2020

Iryna Pyvovar et al. /// Inactivity of public authority as a subject of land ...360-375

DOI: http://dx.doi.org/10.46925//rdluz.31.22

grounds to refer the relevant rule to the legal system of "dead law". Now in Ukrainian land management is undefined the mechanism of state registration of land plots, formed under the land management plan, developed without obtaining the relevant permission for its production, but under the procedure of "tacit consent". This is caused by the fact that according to part (3) of article (24) of the Law On the State Land Cadaster No. 3613-VI on 7/7/2011:

state registration of land plots is carried out by an application of: an individual who by the decision of executive authority, local self-government authority has been granted permission to develop documentation for land management, which is the basis for the formation of a land plot, while its transferring into ownership or use from lands of state or communal property, or by a person authorized by it.

From the above it follows that existence of the mentioned permission, issued by the decision of the relevant authority, is an obligatory prerequisite for the state registration of a land plot. The analysis of the Law No 3613-VI gives grounds to state the absence of special provisions in it that will allow (permit) the state registration of land without the existence of a special document, that is, under the procedure of principle of "tacit consent".

Thus, despite the fact that land legislation has a declaratory rule on the possibility to allocate land plots into ownership on the basis of the principle of tacit consent, on the other hand, due to the lack of a clear mechanism for implementation of this principle at the stage of obtaining permission for the development of documentation on land management in case of no response within the term defined by the law (that is, in the case of unlawful inactivity of the power entity) an applicant, although has a positive right to order a plan of allocation of a land plot, however, in the future its implementation does not contribute to exercising the right of such citizen to obtain the land plot into ownership.

4.3. Ways of Protection Rights of an Individual During Consideration and Decision of His/Her Application for Permission to Prepare Land Management Documentation Concerning the Allocation of a Land Plot

In conflict situations caused by the uncertainty of the land legislation and by the abuse of the authorities when considering the citizens' applications for granting permission to prepare land management documentation concerning the allocation of a land plot into ownership, there is a need to protect the violated rights. 
REVISTA DE LA UNIVERSIDAD DEL ZULIA. 3época. Año 11 N 31, 2020 Iryna Pyvovar et al. /// Inactivity of public authority as a subject of land ...360-375 DOI: http://dx.doi.org/10.46925//rdluz.31.22

If there is the need to protect our rights, we should first of all point to article (13) of the Convention for the Protection of Human Rights and Fundamental Freedoms, which provides that everyone whose rights and freedoms, determined by this Convention, have been violated, is entitled to an effective legal protection in national authority, even if the violation was committed by individuals exercising their official powers (1950).

Therefore, when deciding how to protect the violated right, one should also take into account its effectiveness from the point of view of article (13) of the Convention for the Protection of Human Rights and Fundamental Freedoms (1950). In paragraph (145) of the Decision of November 15, 1996 in the Case "Chahal v. The United Kingdom" Chahal v. The United Kingdom (22414/93) [1996] ECHR 54) the European Court of Human Rights stated that at national level the said rule ensures effective legal remedies for exercising rights and freedoms, provided in the Convention, regardless of how they are expressed in the legal system of any country (1996).

Thus, the essence of this article is limited to request to grant the applicant such legal remedies at the national level that would allow the competent state authority to examine the merits of the complaint on violation of the Convention and to provide appropriate judicial protection. Such request was accepted, despite the fact that States parties of the Convention have some discretion in choosing how to enforce their obligations. In addition, the ECHR noted that under some circumstances the requirements of article (13) of the Convention can be met by all the means provided under national law (Decision of the European Court of Human Rights in Case "Chahalv. The United Kingdom" No. 22414/93 for 1996).

The above-mentioned article (13) of the Convention requires of States parties that the rules of national legal remedies deal with a matter of "not unfounded application" under the Convention and provide an appropriate compensation. The content of the obligations according to article (13) also depends on the nature of the applicant's complaint under the Convention. However, the remedy of protection that is required by the said article should be "effective" both in law and in practice, in particular in that sense that its use was not complicated by the actions or inactivity of the authorities of the certain State (para.75) (Decision of the European Court of Human Rights in Case "Afanasyev v. Ukraine" No. 38722/02 for 2005). 
REVISTA DE LA UNIVERSIDAD DEL ZULIA. 3época. Año 11 N 31, 2020

Therefore, "an effective remedy of the legal protection" under the Article 13 of the Convention shall ensure restoration of violated right and achievement of the desired result; making decisions that do not directly change the scope of rights and provide their enforcement, does not meet the international rule under consideration.

\subsection{Discretionary Powers of Public Authorities in Land Permitting Legal Relations}

However, there is another aspect of the issue. It is characterized by the discretionary powers of the public authorities. In practice and science, the term is connected with so-called freedom of the authority to the right to choose between a positive and a negative decision for an applicant (Bondarchuk \& Storozhuk, 2019). As the case-law of courts in Ukraine is characterized by the lack of common approaches to the ability of a court to interfere in discretionary powers, and herewith positions differ depending on the method of defense chosen by the plaintiff (Slobodian, 2016), this issue in land disputes is rather relevant today.

In the absence of certainty in the Ukrainian legislation on this issue, practicing lawyers resort to studying and using European Union acts as a basis. The basic definition of the concept of discretionary powers conventionally is determined by the Council of Europe in Recommendation № $\mathrm{R}(80) 2$. According to this act, the discretionary powers of an administrative authority are powers, which an administrative authority, when deciding, can exercise with some discretion, that is, when such an authority can choose one out of several legally acceptable decisions, which under the circumstances is considered to be the best one (1980).

Obviously, such discretion is mainly actualized in cases of refusal of the public authority to grant a motion of an applicant, or in the case of its ignoring. Therefore, in such situations, the "aggrieved" citizens rely mainly on court. However, it should be kept in mind that in such relations a court cannot substitute a public authority, decision of which is disputed, make decisions, which are declared to be unlawful, another decision that would be regulated by law, and give instructions that would indicate the resolution of issues that fall within the competence of such power entity, since such actions are beyond powers vested by the legislator.

According to para. (4) part (1) of article (5) of the Code the way to protect person's rights from unlawful inaction is to recognize the inactivity of the power entity as unlawful, 
REVISTA DE LA UNIVERSIDAD DEL ZULIA. 3época. Año 11 N 31, 2020

Iryna Pyvovar et al. /// Inactivity of public authority as a subject of land ...360-375

DOI: http://dx.doi.org/10.46925//rdluz.31.22

as well as the obligation to take certain actions (Code of Administrative Justice of Ukraine No. 2747-IV for 2005). That is, the actions that the appropriate authority should take, based on the legal requirements.

In the relevant disputed land "discretionary" relations appealing to a court, citizens expect the effective action according to para. (4) part (2) of article (245) of the Code, the content of which suggests that in the case of sustaining an administrative claim, the court can make a decision on recognizing inactivity of the power entity as unlawful and oblige to take certain actions (Code of Administrative Justice of Ukraine No. 2747-IV for 2005). However, the analysis of the mentioned rules also shows that such powers can be exercised by a court only in case of established fact of violation of the rights, freedoms or interests of the plaintiff and the need for their restoration.

In case of non-fulfillment of obligation by the defendant (authority), in the existence of the conditions stipulated by law, a court really has grounds for effective protection of the infringed right of a plaintiff, including obligation of a defendant to take certain actions aimed at restoring violated right, in particular, make a decision.

According to part (2) of article (19) of the Constitution of Ukraine public authorities and local self-government bodies, their officials are obliged to act only on the basis, within the powers and in the manner provided by the Constitution and laws of Ukraine (Constitution of Ukraine, No. 254k/96-VR for 1996). Therefore, a court is empowered to oblige a defendant to make a decision, and this is directly apparent in para. (4) part (1) of article (5) and para. (4) part (2) of article (245) of the Code of Administrative Justice of Ukraine No. 2747-IV (2005).

As was noted above, there is no concept of "discretionary powers" of the power entity in Ukrainian legislation. On this opportunity, the case-law of courts has already formed a position concerning the concept of discretionary powers, which are generally understood as such powers when, within the limits specified by law, an administrative body has the opportunity (in its discretion) to choose independently one of several ways of a specific lawful decision (Decisions of the Higher Administrative Court of Ukraine in Cases: No. K/800/6863/15 on 16/6/2015; No. K/800/17306/16 on 16/11/2016; No. K/800/17393/16 on 16/11/2016; No. K/800/13317/15 on 29/9/2016; No. K/800/32134/15 on 17/12/2015). 
REVISTA DE LA UNIVERSIDAD DEL ZULIA. 3época. Año 11 N 31, 2020 Iryna Pyvovar et al. /// Inactivity of public authority as a subject of land ...360-375

DOI: http://dx.doi.org/10.46925//rdluz.31.22

At the same time, according to one of the positions of the Supreme Court powers of state bodies are not determined as discretionary, when there is only one rightful and legally substantiated way of behavior of power entity. That is, in the case of the conditions set by the legislation the defendant is obliged to take specific actions and, if he doesn't take them, he can be obliged to do it through legal proceedings (Decision of the Higher Administrative Court of Ukraine in Case No. K/31204/15 on 17/12/2015).

Thus, in the case of absence in power entity the legally enshrined right of administrative discretion in taking actions/making a decision, and the establishment of the fact of the unlawful conduct of the defendant through legal proceedings, court's obligation of the subject to make a decision of specific content cannot be considered an interference with discretionary powers, because this way to protect the violated right is the most effective and aimed at preventing arbitrariness in public authorities.

In legal relations concerning granting a permission/refusal for the development of land management plan for a land plot allocation, to the subjective right of an applicant to develop documentation for land management concerning a land plot allocation is corresponded legal obligation of the defendant (public authority) to grant such permission or make motivated decision concerning refusal in its granting. In this case, there is an administrative discretion while committing actions/making a decision. Therefore, the issues of transferring a land plot into ownership (use) are discretionary powers of a power entity, in which the court cannot interfere.

Turning to the analysis of the case-law of courts, previously it can be noted that it also differs in terms of referring the powers of a public administration body to grant permission/refusal to develop a land management plan to discretionary ones. Generalizing this practice generally leads to the conclusion that the Supreme Court, as a rule, refers such powers to discretionary ones (Decision of the Supreme Court in Case No. 814/358/16 on $13 / 6 / 2018)$.

However, there is also the opposite case-law of courts. Thus, in the case of the Supreme Court in Case No. 806/2208/17, the panel of judges concluded that the powers of state bodies are not discretionary, when there is only one legitimate and legally substantiated way of behavior of power entity (2018). That is, in the case of the conditions set by the legislation the defendant is obliged to take specific actions and, if he doesn't take them, he can be obliged to do it through legal proceedings (Decision of the Higher Administrative Court of Ukraine 
REVISTA DE LA UNIVERSIDAD DEL ZULIA. 3época. Año 11 N³1, 2020

in Case No. K/31204/15 on 17/12/2015). This means that the discretionary power can consist in choosing to act, not to act, and if to act, then in choosing a way of a decision or action among the ways, which are directly or indirectly enshrined in the law. An important feature of this choice is that it is made without the need to agree the choice with anyone. The powers to grant permission for the development of a land management plan or to provide a reasonable refusal to grant it are regulated by part (6) of article (118) of the Land Code No. 2768-III for 2001. The conditions under which the authority refuses to grant permission are determined by law. If there are no such conditions, the authority should grant permission. These powers and the order of their exercising provide only one type of lawful conduct of the appropriate public authority - to grant permission or not (to refuse). According to law, this public authority has no choice between several possible legitimate decisions. In such case, these powers are not considered to be discretionary ones (Decision of the Supreme Court in Case No. 807/3072/14 on 27/6/2018).

\subsection{Choosing an Effective Way to Protect the Rights and Interests of an Individual}

At the same time, the issue of choosing an effective way of protecting the rights and interests of an individual because of unlawful decision, action or inactivity of a public administration body remains debatable. In this, primarily, differs the case-law of courts. The analysis of the Supreme Court's decisions allows to state that in the case of recognizing actions of defendant as unlawful (public authority) or its inactivity in making decision concerning granting/refusal to grant permission for the development of a land management plan, a court, as a rule, obliges such power entity to re-examined application on granting permission for the development of a land management plan regarding the allocation of a land plot into ownership with the adoption of reasonable and legal decision.

It is worth mentioning another position of the Supreme Court, which consists in combining two different approaches. Thus, in Case № 806/2208/17 on 11/4/2018 the court found as unlawful inactivity of the authorized subject, which is manifested in the rejection by him of any of the decisions provided in part 6 of Art. 118 of the Land Code of Ukraine, within the time limit specified by law, a proper way of protecting the rights of the plaintiff. On this basis, the court rendered a decision, in which it provided actually new procedure, which consists in the following (2018): 
REVISTA DE LA UNIVERSIDAD DEL ZULIA. 3ª época. Año 11 N 31, 2020

Iryna Pyvovar et al. /// Inactivity of public authority as a subject of land ...360-375

DOI: http://dx.doi.org/10.46925//rdluz.31.22

on the one hand, it obliged the authorized body (the Main Directorate of the State GeoCadastre in the Zhytomyr region) to make an appropriate decision, that is a decision on granting or refusal to grant permission for the development of a land management plan for allocation of a land plot into ownership;

on the other hand, ordered (allowed) the claimant to use the "tacit consent" principle in the following cases:

A) in case of failure to adopt the above decision in the proper form within the period prescribed by law, that is in the case of unlawful inactivity of the defendant, a person interested in obtaining free of charge ownership of a land plot from state or communal property;

B) and in the case of making a decision in the proper form by an appropriate body to refuse to grant permission on grounds, which an individual considers illegal. In this case, a court decision can be basis for the development of the land management plan for a land plot allocation into ownership. Nevertheless, according to Art. 22 of the Law No 858-IV land management is carried out on the basis of: a) decisions of executive authorities and local selfgovernment bodies on the implementation of land management; b) concluded contracts between legal or natural entities (landowners and land users) and developers of documentation on land management; c) court decisions (On Land Management. Law of Ukraine, No. 858-IV for 2003);

C) in the case of making an unlawful decision in the form of unlawful refusal to grant permission for the development of a land management plan for land plot allocation into ownership.

The above allows us to summarize the position of the court: refusal of a relevant executive authority or a local self-government body to grant permission to develop a land management plan for allocation of a land plot or a reasonable refusal to grant it within the set time limit does not prevent the development of a land management plan for allocation of a land plot, since an individual has the right to design such plan independently. Therefore, permission for the development of a land management plan for a land plot allocation is not a decision, without which the right to obtain a land plot into ownership cannot be exercised (Decision of the Supreme Court in Case No. 806/2208/17 on 11/4/2018).

At the same time, one should also pay attention to the aspect that the way of restoration of the infringed right should be effective and such that excludes further unlawful decisions, actions or inactivity of power entity, and in the case of non-enforcement or improper enforcement of the decision, the need to re-appeal to court would not have arisen, and enforcement of the decision would be carried out (Decision of the Supreme Court in Case No. 21-1265al5 on 16/9/2015). In case when the court sustain a citizen's claim, it is expected that the decision should be such as to guarantee the observance and protection of the rights, freedoms and interests of such plaintiff against violations of the defendant - power entity, ensure the enforcement of such decision and prevent the need for further appeals to court 
REVISTA DE LA UNIVERSIDAD DEL ZULIA. 3época. Año 11 N 31, 2020

Iryna Pyvovar et al. /// Inactivity of public authority as a subject of land ...360-375

DOI: http://dx.doi.org/10.46925//rdluz.31.22

(Decision of the Higher Administrative Court of Ukraine in Case No. 457/1003/15-a on 29/9/2016).

Conclusions

Legal analysis of the current legislation and the case-law of courts shows that at the present stage of land reform in Ukraine there is no right of power entity, in particular local self-government bodies, to refrain from making the appropriate decision according to the results of citizens' request for permission for the development of a land management plan for a land plot allocation. This gives reasons for the interested parties, the courts to recognize the fact that no response by the authorized body to the "land" appeal of the citizen as unlawful inactivity of the power authority, which is to ignore the request/application of citizens. The form of such unlawful inactivity should also be recognized as a response in the form of a letter of refusal with violation of the month term established by law.

The available form of counterbalance of unlawful inactivity of the public authority in land relations, although is enshrined in the Ukrainian legislation as a principle of tacit consent, but it is of declarative "unrealistic" nature, since there is no regulatory mechanism for the implementation of this principle. At the stage of obtaining permission for the development of documentation for land management in case a citizen does not receive the answer within the time limit set by law, although there is a positive right to order the plan of land plot allocation, however, its implementation in the further would not help the citizen in achieving the main goal to obtain a land plot into ownership.

Considering the discretion of the powers of the authorities in land relations "cover" for manipulation and abuse, interference of the court in administrative powers is considered legitimate, in particular, in cases of absence in power entity legally enshrined right to administrative discretion while taking actions or making decisions. In case of establishing through legal proceedings the fact of unlawful behavior (unlawful inactivity) of the power entity, it is considered that a court has the right to make a decision of a specific content of binding nature, even if it concerns discretionary powers, since this way of protection of the violated right can be considered the most effective and sufficient to prevent arbitrariness in the authorities and to promote protection of constitutional rights of citizens. 
REVISTA DE LA UNIVERSIDAD DEL ZULIA. $3^{a}$ época. Año 11 N 31, 2020

Iryna Pyvovar et al. /// Inactivity of public authority as a subject of land ...360-375

DOI: http://dx.doi.org/10.46925//rdluz.31.22

\section{References}

Bondarchuk, N. V., \& Storozhuk, K. I. (2019). Discretional Authorities in the Context of the Realization of Land Legal Relations in Ukraine. Comparative and analytical law, 3: 115-117. DOI https://doi.org/10.32782/2524-0390/2019.3.28

Code of Administrative Justice of Ukraine, No. 2747-IV for 2005.

Concerning the Exercise of Discretionary Powers by Administrative Authorities, Recommendation of the Council of Europe No. R(80)2 for 1980.

Constitution of Ukraine, No. 254k/96-VR for 1996.

Convention for the Protection of Human Rights and Fundamental Freedoms of the Council of Europe, 1950.

Decision of the European Court of Human Rights in Case "Afanasyevv. Ukraine", No. 38722/02 for 2005.

Decision of the European Court of Human Rights in Case "Chahal v. The United Kingdom", No. 22414/93 for 1996.

Decision of the Higher Administrative Court of Ukraine in Case No. K/31204/15 on $17 / 12 / 2015$.

Decision of the Higher Administrative Court of Ukraine in Case No. 457/1003/15-a on 29/9/2016.

Decision of the Higher Administrative Court of Ukraine in Case No. K/800/6863/15 on 16/6/2015.

Decision of the Higher Administrative Court of Ukraine in Case No. K/800/17306/16 on 16/11/2016.

Decision of the Higher Administrative Court of Ukraine in Case No. K/800/17393/16 on 16/11/2016.

Decision of the Higher Administrative Court of Ukraine in Case No. K/800/13317/15 on 29/9/2016.

Decision of the Higher Administrative Court of Ukraine in Case No. K/800/32134/15 on 17/12/2015.

Decision of the Supreme Court in Case No. 21-1265al5 on 16/9/2015.

Decision of the Supreme Court in Case No. 750/8511/17 on 19/6/2018.

Decision of the Supreme Court in Case No. 806/2208/17 on 11/4/2018.

Decision of the Supreme Court in Case No. 807/3072/14 on 27/6/2018. 
REVISTA DE LA UNIVERSIDAD DEL ZULIA. 3época. Año 11 N 31, 2020 Iryna Pyvovar et al. /// Inactivity of public authority as a subject of land ...360-375

DOI: http://dx.doi.org/10.46925//rdluz.31.22

Decision of the Supreme Court in Case No. 814/358/16 on 13/6/2018.

Draft Law on Amendments to Certain Legislative Acts of Ukraine Concerning the Circulation of Agricultural Lands, No. 2178 on 25/9/2019.

Land Code of Ukraine, No. 2768-III for 2001.

Law of Ukraine on Land Management, No. 858-IV for 2003.

Law of Ukraine on the State Land Cadaster, No.3613-VI for 2011.

Resolution of the Supreme Court in the Case No. 806/3095/17 on 10/07/2018.

Slobodian, B. (2016, November). In which cases can a court disregard the discretion of a public authority? Law "EQUITY". Company URL: https://equity.law/images/publication/news name/uj-11-2016-45-53.pdfv 